\title{
Respiratory exposures associated with silicon carbide production: estimation of cumulative exposures for an epidemiological study
}

\author{
T J SMITH, S KATHARINE HAMMOND, F LAIDLA W, AND S FINE \\ From the Occupational Health Program, Harvard School of Public Health, Boston, Mass 02115, USA
}

ABSTRACT Silicon carbide is produced by heating a mixture of petroleum coke and silica sand to approximately $2000^{\circ} \mathrm{C}$ in an electric furnace for 36 hours. During heating, large amounts of carbon monoxide are released, sulphur dioxide is produced from residual sulphur in the coke, and hydrocarbon fume is produced by pyrolysis of the coke. Loading and unloading furnaces causes exposures to respirable dust containing crystalline silica, silicon carbide, and hydrocarbons. In the autumn of 1980 extensive measurements were made of personal exposures to air contaminants. Eight hour time weighted exposures to sulphur dioxide ranged from $<0.1 \mathrm{ppm}$ to $1.5 \mathrm{ppm}$ and respirable participate exposures ranged from $0.01 \mathrm{mg} / \mathrm{m}^{3}$ to $9.0 \mathrm{mg} / \mathrm{m}^{3}$. Geometric mean particulate exposures for jobs ranged from $0.1 \mathrm{mg} / \mathrm{m}^{3}$ to $1.46 \mathrm{mg} / \mathrm{m}^{3}$. The particulate contained varying amounts of $\alpha$-quartz, ranging from $<1 \%$ to $17 \%$, and most quartz exposures were substantially below the threshold limit value of $100 \mu \mathrm{g} / \mathrm{m}^{3}$. Only traces of cristobalite $(<1 \%)$ were found in the particulate. Median exposures to air contaminants in each job were estimated. Since the operations at the plant had been stable over the past 30 years, it was possible to estimate long term exposures of workers to sulphur dioxide, respirable particulate, quartz, total inorganic material, and extractable organic material. Cumulative exposure (average concentration times exposure duration) for each of the air contaminants was estimated for each worker using his job history. There was sufficient independent variability in the sulphur dioxide and respirable particulate cumulative exposures to make an assessment of their independent effects feasible. The theoretical basis for using the cumulative exposure index and its shortcomings for epidemiological applications were presented.

Silicon carbide $(\mathrm{SiC})$ is produced by a process that generates large quantities of carbon monoxide and smaller quantities of other air contaminants: sulphur dioxide and airborne particulate that contains SiC, crystalline silica, other inorganic materials, and organic compounds. The acute health hazards from carbon monoxide explosions and toxicity have long been recognised within the industry. There has been little research on the hazard of chronic lung disease, although the crystalline silica used in the process is recognised as a hazard. One epidemiological study observed pneumoconiosis in SiC production workers, but the exposures were not measured.' Studies of abrasive manufacturers have observed respiratory

Received 21 October 1982

Accepted 6 December 1982 effects, but interpretation was confounded by concurrent exposures to aluminium oxide in addition to silicon carbide. ${ }^{23}$ Animal studies generally have not detected any evidence that $\mathrm{SiC}$ is fibrogenic, ${ }^{4}$ however, one study of quartz effects in rats observed that $\mathrm{SiC}$ appeared to enhance the fibrogenic response when administered concurrently. ${ }^{5}$

The present study originated from a preliminary study by the Départemente de Santé Communautaire (DSC), Centre Hospitalier Régional de la Maurice, Quebec, that showed a significant increase in opacities on chest radiographs and decrease in spirometric pulmonary function among $\mathrm{SiC}$ production workers. The preliminary study did not collect data on exposures and did not use complex epidemiological analysis. Thus a second study was undertaken with the following objectives: (1) to measure the current exposures to air contaminants; 
(2) to estimate the long term exposures to air contaminants; and (3) to use the exposure data in a reanalysis of the previously collected data on pulmonary effects. The first two objectives will be addressed in the present paper and the epidemiological analysis will be covered in another paper. ${ }^{6}$

Although few workers are directly concerned in silicon carbide production, the importance of the present study lies in the widespread industrial exposures to $\mathrm{SiC}$, crystalline silica, hydrocarbons, and sulphur dioxide (singly and in combination).

\section{Silicon carbide process and plant description}

$\mathrm{SiC}$ is produced by mixing petroleum coke, high purity crystalline silica, and sawdust, and then heating the mixture to $2000-2200^{\circ} \mathrm{C}$ for about 36 hours (fig 1). Silica reacts with the carbon in the coke to produce silicon carbide and carbon monoxide. Sulphur, an impurity in the coke $(2-4 \%)$, is released as $\mathrm{SO}_{2}$. A wide variety of hydrocarbons are also released by

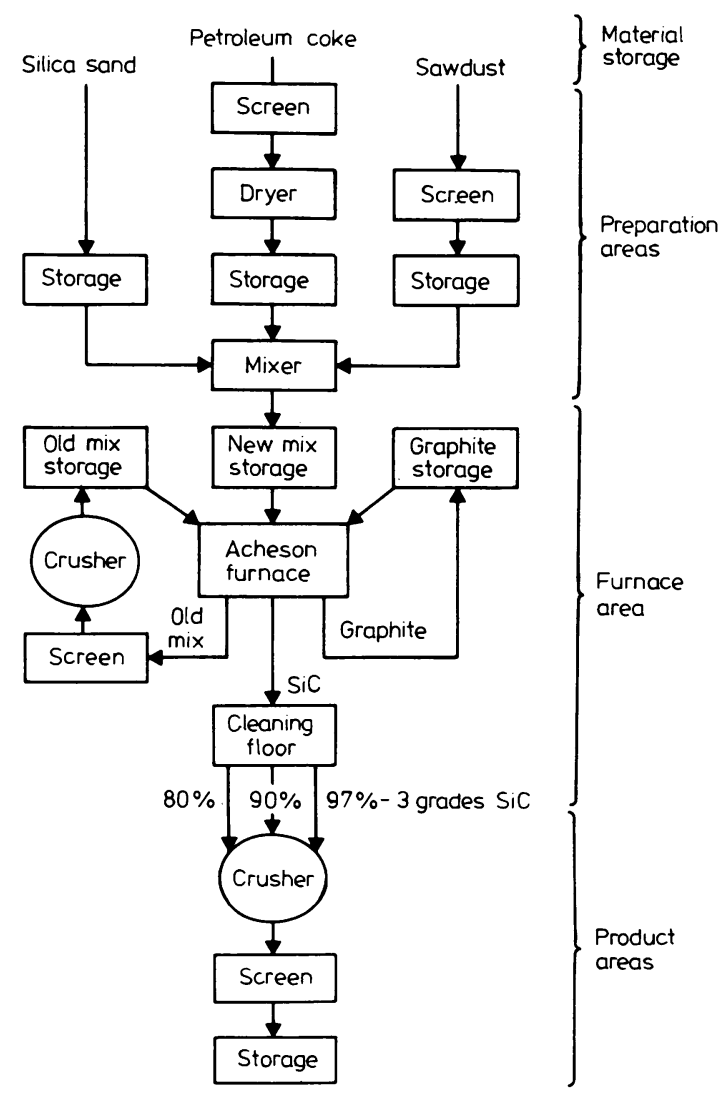

Fig 1 Production of silicon carbide. the pyrolysis of the coke, which is similar to the destructive distillation of coal in the coke oven process. Sawdust is added to the mixture to reduce its density so that gaseous carbon monoxide may be easily vented.

The plant uses Acheson furnaces, which are heated by a direct current flowing through powdered graphite laid in a strip within the charge mixture (fig 2 ). The charge is thermally insulated by layers of "old mix," which is the residue of charge not converted to $\mathrm{SiC}$, and contains approximately $80 \%$ sand and $20 \%$ low grade $\mathrm{SiC}$. The furnace is charged by an overhead crane, which lays down successive layers of materials (fig 2).

Each furnace is fired for about 36 hours. During heating large quantities of carbon monoxide are released, which burn at the surface of the furnace. Increasing amounts of hydrocarbon fume (particulate) and sulphur dioxide are also released. No one works on the furnace during the heating cycle, but many work nearby.

After the heating cycle, the furnace is disassembled in stages to allow it to cool as rapidly as possible: the sides of the furnace are removed; the $\mathrm{SiC}$ is removed in large lumps; the graphite conductor is set aside for reuse; and the old mix is removed to the "revert" area for recycling. Before 1962, this process was performed manually by workers wearing thick soled shoes so that they could walk directly on the hot furnace. In 1962 the process was mechanised with overhead cranes and front end loaders.

On the cleaning floor, in the centre of the old furnace building (fig 3), workers with pneumatically powered chisels break up the large lumps of $\mathrm{SiC}$ and sort it into three grades. This is completed in a series of four or five short work periods, about 30 minutes each, during a shift. The crane loads the cleaning floor with SiC before each work period while the workers rest in a small enclosed lunch room.

All grades of final product are crushed and screened into several sizes, stored, and shipped out to users who will make abrasive products with them.

Figure 3 shows a diagram of the plant indicating the relative locations of the work areas. The main, or old, furnace building has about $\mathbf{4 0}$ furnaces, and the new furnace building has another 15 . The furnaces are operated in groups of four with one under heat while the others are in various stages of construction and cooling. Furnaces are constructed and disassembled five days a week, while maintenance and repair work are performed at the weekend. Furnaces are fired over the weekend but they are not constructed or disassembled. Thus with the exception of Monday's first shift, when furnaces heated over the weekend are disassembled and rebuilt, there are always some furnaces under heat 


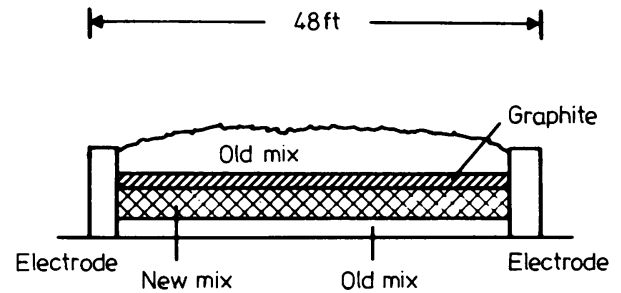

(a) Longitudinal section of Acheson furnace, before firing

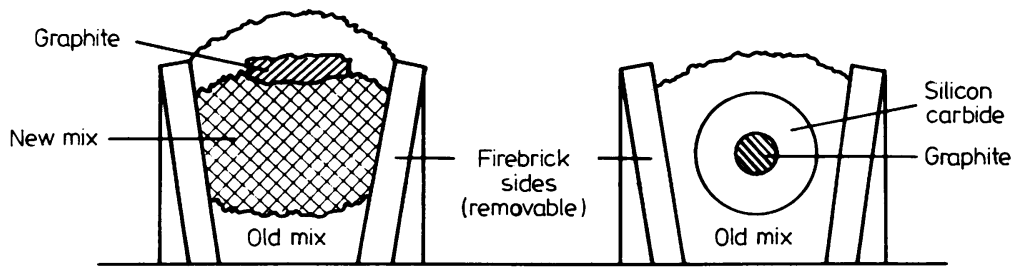

Fig 2 Firing of silicon carbide in Acheron furnace.

(b) Cross sectional view, before firing

(c) Cross sectional view, before firing

24 hours a day. Even on Mondays there are emissions from the furnaces that have just begun to cool from being heated over the weekend.

The nature of the production process has been unchanged over the past 50 years except as noted above. The level of production has been nearly constant $( \pm 15 \%)$ over this period and was significantly reduced only during relatively short periods of construction and process modification in 1957 and 1961-3. The sulphur content of the petroleum coke has varied depending on the supplier and the availability of low sulphur oil. Currently the sulphur level is being maintained at about $3 \%$ by blending high and low sulphur cokes.

Table 1 gives descriptions of work activities of each of the major job categories at the plant. Table 2 gives a breakdown of the plant work force by work area and job. Most of the work force is employed in the furnace area.

\section{Methods and materials}

Exposures were measured by personal sampling, and sample collection was stratified by job category and work area as shown in table 2. Emphasis was placed on evaluation of furnace area exposures. Samples from two to four full shifts were collected on some individuals to determine their day to day variation in exposure. A total of 182 personal samples were collected. Fifteen samples were collected to measure $\mathrm{SO}_{2}$ exposure. A direct reading instrument (Ecolyzer) was used to measure the concentration of carbon monoxide in several locations within the furnace area.

Respirable particulate was collected on a tared

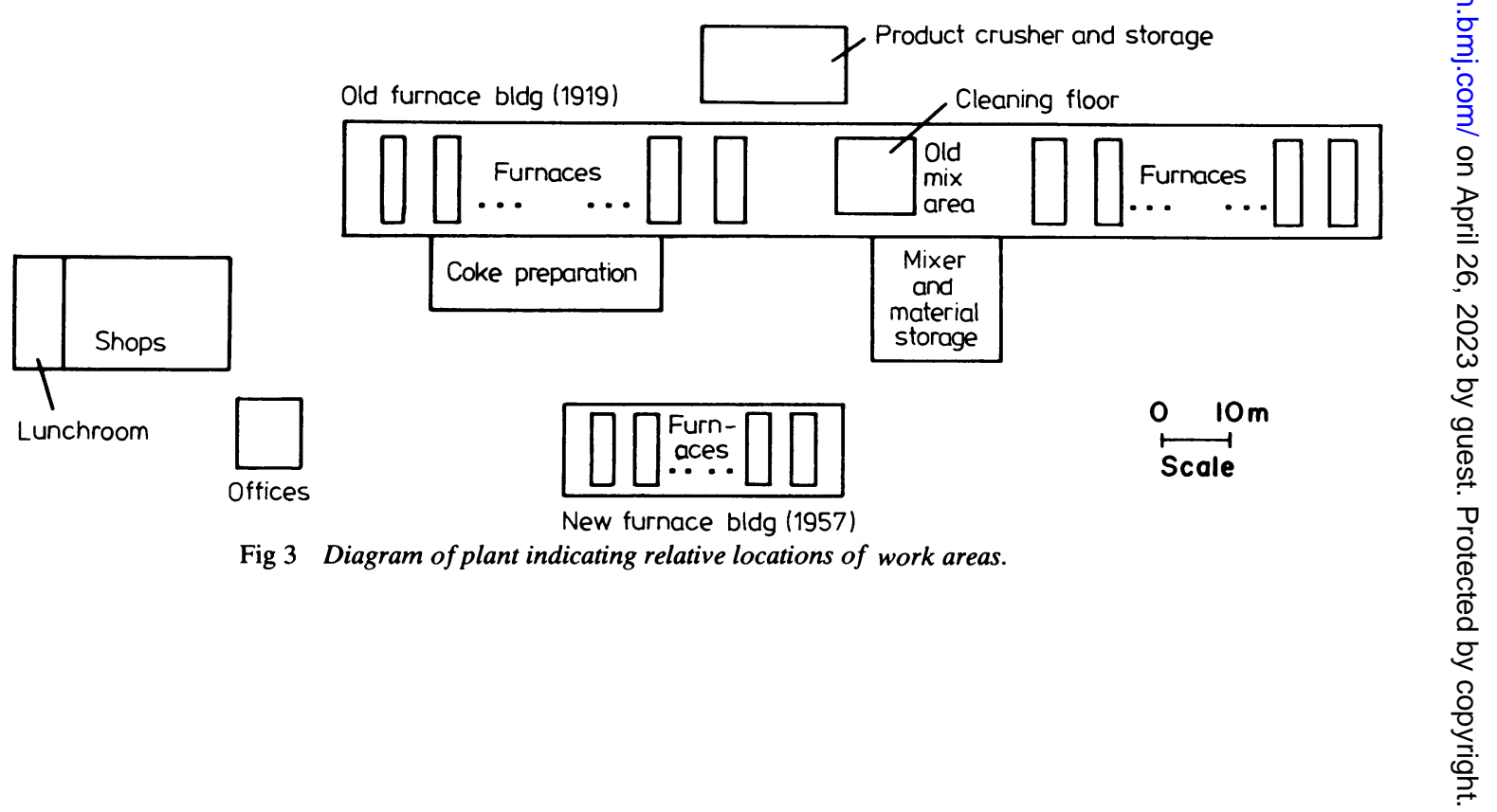


Table 1 Job descriptions of plant workers

\begin{tabular}{|c|c|}
\hline Exposure area/job & Description \\
\hline Outdoor areas & $\begin{array}{l}\text { Labourers and others who unload } \\
\text { raw materials from railroad cars } \\
\text { and stock piles and perform } \\
\text { miscellaneous jobs }\end{array}$ \\
\hline $\begin{array}{l}\text { Preparation areas: } \\
\text { Coke preparation }\end{array}$ & $\begin{array}{l}\text { Coke dryer operator and helpers } \\
\text { attend operation of crusher, dryer, } \\
\text { screens, and conveyor and storage } \\
\text { systems }\end{array}$ \\
\hline Sawdust and sand & $\begin{array}{l}\text { Attendants operate payloader, } \\
\text { attend vibrating classifier and } \\
\text { conveyor and storage systems } \\
\text { for sawdust and sand }\end{array}$ \\
\hline Mixer & $\begin{array}{l}\text { Operator monitors blending of } \\
\text { sand, coke, and sawdust by mixing } \\
\text { machine that prepares "new mix" }\end{array}$ \\
\hline $\begin{array}{l}\text { Furnace area: } \\
\text { Craneman }\end{array}$ & $\begin{array}{l}\text { Operates overhead crane that rides } \\
1 \text { m above tops of furnaces; loads } \\
\text { furnace with old mix, new mix, } \\
\text { and graphite; removes sides of } \\
\text { furnaces; strips off contents } \\
\text { of completed furnaces while hot; } \\
\text { and transports silicon carbide to } \\
\text { cleaning floor }\end{array}$ \\
\hline Furnace loader & $\begin{array}{l}\text { Helps crane operator in construction } \\
\text { of furnace; walks along top of } \\
\text { furnace guiding hopper of damp } \\
\text { charge }\end{array}$ \\
\hline Furnace labourer & $\begin{array}{l}\text { Performs various jobs including: } \\
\text { putting up and removing sides; } \\
\text { clean up around furnaces; and } \\
\text { miscellaneous tasks }\end{array}$ \\
\hline Electrode cleaner & $\begin{array}{l}\text { Maintains furnace electrodes by } \\
\text { cleaning, removing damaged } \\
\text { materials, and reconstructing them }\end{array}$ \\
\hline $\begin{array}{l}\text { Payloader oper- } \\
\text { ator }\end{array}$ & $\begin{array}{l}\text { Cleans area of old mix after } \\
\text { silicon carbide has been removed } \\
\text { from a cooling furnace; old mix is } \\
\text { dumped in bins for recycling }\end{array}$ \\
\hline Old mix operator & $\begin{array}{l}\text { Operates a front end loader to } \\
\text { transfer old mix from piles on } \\
\text { floor into recycling system }\end{array}$ \\
\hline Carboselector & $\begin{array}{l}\text { Works on cleaning platform, uses } \\
\text { a pneumatic hand tool to separate } \\
\text { large lumps of silicon carbide into } \\
\text { various grades; workers process } \\
\text { four to five batches of carbide a } \\
\text { shift }\end{array}$ \\
\hline Maintenance & $\begin{array}{l}\text { Several jobs: many are composite } \\
\text { jobs, millwright-oiler, mechanic } \\
\text { welder, etc }\end{array}$ \\
\hline Supervisor & $\begin{array}{l}\text { Several jobs: leader furnace repair, } \\
\text { foreman, assistant foreman, shift } \\
\text { leader, etc }\end{array}$ \\
\hline Product area & $\begin{array}{l}\text { Several jobs: belt picker, crusher } \\
\text { operator, assistant crusher operator }\end{array}$ \\
\hline $\begin{array}{l}\text { Shop, laboratory, } \\
\text { and office areas }\end{array}$ & $\begin{array}{l}\text { Several jobs: welder, layout man, } \\
\text { truck driver, storekeeper, gate } \\
\text { man, janitor, accountant, chemist, } \\
\text { etc }\end{array}$ \\
\hline
\end{tabular}

filter, which was preceded by a $10 \mathrm{~mm}$ nylon cyclone to remove non-respirable particles. Two types of filters were used: a $5.0 \mu \mathrm{m}$ pore diameter, PVC membrane filter (type \#WS-B, Mine Safety Appliance Co, Pittsburgh, PA) and a Teflon coated glass fibre filter (type T60 A20 Pallflex Products Corp, Putnam, CT). Half the samples in each job or work area were obtained with each filter type: the PVC for $x$ ray diffraction analysis and the glass fibre
Table 2 Workforce, number of workers sampled, and total number of respirable particulate samples by work area and job

\begin{tabular}{|c|c|c|c|}
\hline Work area or job & $\begin{array}{l}\text { Total } \\
\text { workforce }\end{array}$ & $\begin{array}{l}\text { No of workers } \\
\text { sampled }\end{array}$ & $\begin{array}{l}\text { Total No of } \\
\text { samples }\end{array}$ \\
\hline $\begin{array}{l}\text { Outdoor areas: } \\
\text { Payloader } \\
\text { Labourer }\end{array}$ & $\begin{array}{l}2 \\
8\end{array}$ & $\begin{array}{l}2 \\
2\end{array}$ & $\begin{array}{l}2 \\
2\end{array}$ \\
\hline $\begin{array}{l}\text { Preparation areas: } \\
\text { Coke preparation } \\
\text { Sawdust and sand } \\
\text { Mixer }\end{array}$ & $\begin{array}{l}9 \\
3 \\
7\end{array}$ & $\begin{array}{l}2 \\
1 \\
2\end{array}$ & $\begin{array}{l}4 \\
2 \\
5\end{array}$ \\
\hline $\begin{array}{l}\text { Furnace areas: } \\
\text { Cranemen } \\
\text { Furnace loader } \\
\text { Furnace labourer } \\
\text { Electrode cleaner } \\
\text { Asst electrode } \\
\text { operator } \\
\text { Payloader } \\
\text { operator } \\
\text { Old mix operator } \\
\text { Carboselector } \\
\text { Maintenance } \\
\text { Product area } \\
\text { Shop }\end{array}$ & $\begin{array}{r}14 \\
5 \\
7 \\
3 \\
6 \\
6 \\
8 \\
5 \\
30 \\
32 \\
3 \\
8\end{array}$ & $\begin{array}{r}10 \\
2 \\
7 \\
3 \\
4 \\
\\
8 \\
5 \\
15 \\
6 \\
1 \\
5\end{array}$ & $\begin{array}{r}20 \\
4 \\
14 \\
5 \\
\\
8 \\
\\
13 \\
7 \\
24 \\
8 \\
1 \\
5\end{array}$ \\
\hline
\end{tabular}

for hydrocarbon analysis. The glass fibre filters were extracted with methylene chloride before use to remove contamination. All samples were refrigerated after sampling to minimise losses of volatile hydrocarbons.

$\alpha$-Quartz was measured by $x$ ray diffraction after oxidising the PVC filter matrix and sample in a low temperature radio frequency combuster and then depositing the unoxidised residue on a silver membrane filter. ${ }^{7}$ The mass of unoxidised residue was reported as inorganic matter. Because of the relatively low sensitivity of the $x$ ray diffraction technique, all samples from a given job category were composited and analysed as a single sample. Semiquantitative analyses were also performed to determine the approximate amounts of crystobalite and silicon carbide present on the $x$ ray diffraction tracings.

Total extractable organic compounds were determined gravimetrically on an aliquot of a methylene chloride extract of the sample, which was evaporated to dryness. Samples were extracted for 18 hours in a Soxhlet extractor. The polycyclic aromatic hydrocarbon content of some of the extracts was measured semiqualitatively by a fluorescent spot test. ${ }^{8}$

The nicotine content of the methylene extracts was measured by gas chromatography using a nitrogen/phosphorus sensitive flame ionisation detector and $1 \mathrm{~m}$ column of $10 \%$ Carbowax $20 \mathrm{M}$ pretreated with $3 \%$ potassium hydroxide. ${ }^{9}$

Sulphur dioxide was measured by absorption in hydrogen peroxide and titration of the resulting sul- 
phuric acid solution. ${ }^{10}$ Air was drawn at $0.9 \mathrm{l} / \mathrm{min}$ through two midget impingers in series (used as gas scrubbers), each containing hydrogen peroxide. Because of the inconvenience of the sampling system, it was only possible to collect a few personal samples.

Distributions of the exposures were described by log-normal statistics, the geometric mean, and geometric standard deviation because the observations were positively skewed and personal exposure measurements are commonly log-normal. ${ }^{11}$ Analyses of variance were performed on the logarithms of the exposures using the statistical analysis system (SAS). ${ }^{12}$

\section{Estimation of cumulative dose}

The rate an air contaminant deposited in a worker's lungs depends on the air concentration $(x)$, his inhalation rate $(r)$, and the fraction of the inhaled material that is deposited $(f)$. Over a single work shift the amount deposited, the worker's dose $\left(D_{i}\right)$, is the integral of the deposition rate:

$$
D_{i} \cdot=\int_{o}^{t} x r f d t
$$

If the inhalation rate and fraction deposited are approximately constant then his dose on day $i$ may be estimated by the time weighted average air concentration $\left(x_{i}\right)$ in his breathing zone times his average inhalation rate $(r)$, times the fraction of the substance deposited in his lungs $(f)$. Or,

$$
D_{i}=x_{i} r f
$$

For a long term exposure, the total amount of material deposited in the lungs is the sum of each of these daily doses. Thus the cumulative dose, $D$, over a long period, $N$ days, is

$$
D=\sum_{i=l}^{N} x_{i} r f
$$

Since the arithmetic mean of the daily exposures is given by

$$
\bar{x}=\frac{1}{N_{i}} \sum_{i=1}^{N} x_{i}
$$

the cumulative dose can be written as

$$
D=N \bar{x} r \text {. }
$$

Since the cumulative exposure is the product of average concentration times the duration of exposure $(N \bar{x})$, if the inhalation rate and fraction deposited in the lungs are approximately constant then the cumulative dose is proportional to the cumulative exposure. Thus if a worker is exposed to different levels of the same agent in several jobs, the sum of his cumulative exposures in each of the jobs will be proportional to the total amount of the agent deposited in his lungs.

Although the arithmetic mean of an individual's daily exposures was the desired index of his dose level, it was not possible to measure the average exposure of each individual in the study cohort. As an alternative, we used the geometric mean of the average exposures of workers doing a given job. The geometric mean was used because the distribution of average exposures of individuals performing the same job is approximately log-normal. ${ }^{11}$ If the distribution of exposures is truly log-normal then the median of the exposures is estimated by the geometric mean. ${ }^{13}$ Thus the exposure for each job was estimated by the geometric mean of the individual arithmetic mean exposures measured for each job in the 1980 survey. A detailed derivation of this approach and its implications and statistical characteristics is in preparation ( $\mathrm{T} \mathrm{J} \mathrm{Smith).}$

Since workers frequently had a large number of different jobs, many of which had the same levels of exposure, the job histories were condensed into 10 job categories with different exposures for pre-1962 and 1962-80. The duration of exposure in each job category and each period was determined for each subject from his work history at the company. An exposure level was assigned to each of the 10 job categories based on the 1980 data and on information about the nature of the exposures. Cumulative exposures for sulphur dioxide, respirable particulate, $\alpha$-quartz, inorganic material, and extractable organic matter were calculated for each subject using the condensed job histories and the exposure assignments. These cumulative exposures are proportional to the total amount of each substance deposited or absorbed in the subject's respiratory tracts during their total exposures.

\section{Results}

Carbon monoxide (CO) levels were measured in several locations on several days. Average levels ranged from $10 \mathrm{ppm}$ to $25 \mathrm{ppm}$, although brief peaks were seen in the crane cabs as high as 160 ppm for a fraction of a minute, and as high as 80 $\mathrm{ppm}$ for several minutes. The operation of removing the furnace sides produced a large emission of $\mathrm{CO}$. In some locations near the furnaces levels ranging from $100 \mathrm{ppm}$ to $180 \mathrm{ppm}$ were observed for several hours during startup. These areas were not usually active work sites.

The duration of many of the personal exposures was less than eight hours because the workers completed their assigned tasks and returned to the main lunchroom, where they waited for the remainder of the shift (table 3 ). Thus the eight hour time weighted exposures shown in table 3 do not represent the 
Table 3 Eight hour time weighted average, personal respirable dust exposures, and their average durations by job categories and work areas

\begin{tabular}{|c|c|c|c|}
\hline \multirow{2}{*}{$\begin{array}{l}\text { Work area } \\
\text { or job }\end{array}$} & \multirow{2}{*}{$\begin{array}{l}\text { Hours in } \\
\text { work area }\end{array}$} & \multicolumn{2}{|c|}{ Respirable dust $\left(\mathrm{mg} / \mathrm{m}^{3}\right)$} \\
\hline & & $\begin{array}{l}\text { Geometric } \\
\text { mean }\end{array}$ & $\begin{array}{l}\text { Geometric } \\
\text { SD }\end{array}$ \\
\hline $\begin{array}{l}\text { Outdoor areas: } \\
\text { Payloader operator } \\
\text { Labourer }\end{array}$ & $\begin{array}{l}7 \cdot 2 \\
8 \cdot 0\end{array}$ & $\begin{array}{l}1.66 \\
0.65\end{array}$ & $\begin{array}{l}1.59 \\
1.04\end{array}$ \\
\hline $\begin{array}{l}\text { Preparation areas: } \\
\text { Coke prep } \\
\text { Sawdust and sand } \\
\text { Mixer }\end{array}$ & $\begin{array}{l}6 \cdot 7 \\
5 \cdot 3 \\
5 \cdot 9\end{array}$ & $\begin{array}{l}0 \cdot 48 \\
0 \cdot 21 \\
1 \cdot 01\end{array}$ & $\begin{array}{l}2 \cdot 54 \\
1 \cdot 24 \\
1 \cdot 23\end{array}$ \\
\hline $\begin{array}{l}\text { Furnace area: } \\
\text { Cranemen } \\
\text { Furnace loader } \\
\text { Furnace labourer } \\
\text { Electrode cleaner } \\
\text { Asst electrode }\end{array}$ & $\begin{array}{l}4 \cdot 9 \\
5 \cdot 6 \\
5 \cdot 1 \\
4 \cdot 3\end{array}$ & $\begin{array}{l}0.42 \\
0 \cdot 59 \\
0 \cdot 38 \\
0.44\end{array}$ & $\begin{array}{l}2 \cdot 57 \\
1 \cdot 87 \\
2 \cdot 11 \\
1 \cdot 49\end{array}$ \\
\hline $\begin{array}{l}\text { operator } \\
\text { Payloader operator } \\
\text { Old mix operator } \\
\text { Carboselectors } \\
\text { Maintenance: }\end{array}$ & $\begin{array}{l}7 \cdot 2 \\
4 \cdot 4 \\
5 \cdot 7 \\
4 \cdot 6\end{array}$ & $\begin{array}{l}0 \cdot 17 \\
1.46 \\
0 \cdot 85 \\
0.72\end{array}$ & $\begin{array}{l}1 \cdot 67 \\
2 \cdot 17 \\
2 \cdot 73 \\
1 \cdot 58\end{array}$ \\
\hline $\begin{array}{l}\text { General } \\
\text { Millwright } \\
\text { Machinist combo } \\
\text { Electrician }\end{array}$ & $\begin{array}{r}6 \cdot 9 \\
8 \cdot 5 \\
0 \quad 8 \cdot 4 \\
8 \cdot 1\end{array}$ & $\begin{array}{l}0 \cdot 11 \\
0 \cdot 21 \\
0 \cdot 28 \\
0 \cdot 20\end{array}$ & $\begin{array}{l}1.58 \\
2.16 \\
1.99\end{array}$ \\
\hline $\begin{array}{l}\text { Product area: } \\
\text { Crusher operator } \\
\text { Shop: }\end{array}$ & $2 \cdot 9$ & 0.45 & $*$ \\
\hline $\begin{array}{l}\text { Auto mechanic } \\
\text { Welder }\end{array}$ & $\begin{array}{l}8 \cdot 6 \\
8 \cdot 5\end{array}$ & $\begin{array}{l}0.44 \\
1.35\end{array}$ & $\begin{array}{l}4.08 \\
1 \cdot 83\end{array}$ \\
\hline
\end{tabular}

*Only one sample

average air concentration inhaled by the workers in the work area.

Virtually all the workers had some exposure to airborne respirable particulates as shown in table 3 , but the level of the exposure and composition of the dust varied widely as shown in tables 3 and 4 . The outdoor and furnace area payloader operators had high geometric mean, time weighted average exposures to respirable particulate $\left(1.66\right.$ and $1.46 \mathrm{mg} / \mathrm{m}^{3}$ respectively), although less than $10 \%$ of the expos- ures of either exceeded the $5 \mathrm{mg} / \mathrm{m}^{3}$ permissible exposure for respirable nuisance dust. The remainder of the job categories had moderate or low exposures to respirable dust.

Only the furnace loaders had time weighted average exposures to $\alpha$-quartz that frequently exceeded the permissible level allowed by the Province of Quebec, $100 \mu \mathrm{g} / \mathrm{m}^{3} ; 50 \%$ of their $\alpha$-quartz exposures were greater than $100 \mu \mathrm{g} / \mathrm{m}^{3}$. Only four samples were collected, however, so the level of exposure was not well defined. The mixers, payloader operators, old mix operators, and carboselectors had geometric mean exposures to $\alpha$-quartz that were about half of the $100 \mu \mathrm{g} / \mathrm{m}^{3}$ limit. The remainder of the job categories exposures were well below the permissible limit.

$\alpha$-Quartz was the predominant crystalline silica mineral found in the samples. Small amounts of crystobalite were observed in some of the samples, but none exceeded approximately $1 \%$ of the total particulate.

$\mathrm{SiC}$ was presumed to form most of the inorganic portion of the particulate. Large amounts of inorganic material were found in most of the furnace area samples and in all of the product area samples (table 4). The payloader operators had the highest time weighted exposures to inorganic matter.

Large amounts of extractable organic compounds were found in the cranemen's particulate samples. This is consistent with their work location; the open windowed crane cabs are frequently within the stream of hot gases and smoke rising from the furnaces. Other workers generally had low percentages of extractable hydrocarbons in their particulate. The maintenance workers had low levels of extractable hydrocarbons in their samples, but they periodically work in the upper parts of the furnace building (repairing cranes, conveyor belt systems, or other equipment) and during this time their particulate exposures would closely resemble the cranemen's

Table 4 Exposures to sulphur dioxide and constituents of respirable particulate by job category

\begin{tabular}{|c|c|c|c|c|}
\hline Job category & $\begin{array}{l}\mathrm{SO}_{2}^{*} \\
(p p m)\end{array}$ & $\underset{\left(\mu g / m^{3}\right)}{\alpha-Q u a r t z}$ & $\begin{array}{l}\text { Inorganic matter } \\
\left(\mu g / m^{3}\right)\end{array}$ & $\begin{array}{l}\text { Extractable hydrocarbons } \\
\left(\mu g / m^{3}\right)\end{array}$ \\
\hline $\begin{array}{l}\text { Preparatory areas: } \\
\text { Coke } \\
\text { Sawdust } \\
\text { Mixer }\end{array}$ & - & $\frac{28}{50}$ & $\frac{320}{425}$ & - \\
\hline $\begin{array}{l}\text { Furnace area: } \\
\text { Cranemen } \\
\text { Loader } \\
\text { Electrode cleaner } \\
\text { Asst electrode operator } \\
\text { Payloader } \\
\text { Old mix operator } \\
\text { Carboselectors } \\
\text { Maintenance }\end{array}$ & $\begin{array}{l}1.5 \\
1.0 \\
1.0 \\
1.0 \\
1.2 \\
0.2 \\
0.2 \\
0.1\end{array}$ & $\begin{array}{r}10 \\
100 \\
20 \\
15 \\
40 \\
60 \\
55 \\
<10\end{array}$ & $\begin{array}{r}65 \\
170 \\
200 \\
70 \\
570 \\
300 \\
260 \\
190\end{array}$ & $\begin{array}{r}190 \\
15 \\
20 \\
10 \\
25 \\
80 \\
145 \\
-\end{array}$ \\
\hline
\end{tabular}

*These are based on limited samples. 
exposure.

The relatively high level of extractable material in the carboselectors' samples $(20 \%$ of the particulate mass) was probably an artifact caused by the collection of cigarette smoke from the air of their small lunchroom next to the cleaning floor where they wait during their frequent breaks in work. Analyses of the nicotine content of the extractable organic materials showed that the carboselector samples contained an average of $0.049 \%$ nicotine. This was substantially more nicotine than samples from the other seven jobs in the furnace area: only three samples of nine contained any detectable nicotine content $(>0.001 \%)$ and all contained less than $0.015 \%$. The total extractables content of these samples was not, however, correlated with the nicotine content.

Sulphur dioxide exposures were associated with the furnace off-gases, and were highest immediately around the furnaces. One stationary sample indicated a four hour average of $7.3 \mathrm{ppm}\left(18.9 \mathrm{mg} / \mathrm{m}^{3}\right)$ near one of the furnaces. Thus the cranemen, furnace attendants, and the payloader operators were likely to have the highest exposures. Personal, time weighted average samples were all much lower than the stationary samples. Other furnace area workers had low level exposures, and those outside this area had little or no exposure. The assignment of sulphur dioxide exposures in table 4 is tentative because only a few samples were collected.

Analyses of variance (ANOVA) were performed to determine if there were differences in exposure between the morning and afternoon work shifts and among the days of the week. Although there were differences, none was statistically significant $(p>$ $0 \cdot 1)$. Subtle differences may exist that might be detectable with larger sample sizes, but they represent differences of less than a factor of two and in some cases less than $30 \%$ between the geometric means, which are small differences relative to the variability of the measurements.

The collection of multiple samples on some individuals permitted the determination of day to day variation in individual exposures and a comparison of variability among individuals doing the same job. Table 5 shows a summary of the results for four job categories that had sufficient observations for this analysis. Even though these four jobs had a wide range of mean exposures, the day to day variability was larger than the between individual variability for all of them. The number of samples was too small for these differences to be statistically significant.

The cumulative exposures calculated for each subject in the epidemiological study covered a wide range for each of the air contaminants, as shown in table 6 . The results are expressed in concentration times hours times years; for example, the median

Table 5 Comparison of between individual and pooled day to day variability for four job categories

\begin{tabular}{lllll}
\hline Job category & No of individuals & Overall mean* & Between individual SD** & Pooled day to day SD \\
\hline Cranemen & 4 & $0 \cdot 87$ & $1 \cdot 22$ & 1.46 \\
Furnace labourer & 2 & $0 \cdot 70$ & $1 \cdot 28$ & 1.43 \\
Payloader operators & 3 & $3 \cdot 59$ & $2 \cdot 32$ & $2 \cdot 46$ \\
Carboselectors & 6 & $1 \cdot 14$ & $1 \cdot 24$ & $2 \cdot 02$ \\
\hline
\end{tabular}

${ }^{*}$ Geometric mean in $\mathrm{mg} / \mathrm{m}^{3}$.

${ }^{* *}$ Geometric standard deviation (unitless).

Table 6 Descriptive data on cumulative exposure variables for 171 workers in the epidemiological study

\begin{tabular}{|c|c|c|c|c|}
\hline Exposure variable & Mean* & Standard deviation & Median & Range \\
\hline $\begin{array}{l}\text { Sulphur dioxide } \\
\text { Respirable dust } \\
\text { Quartz dust } \\
\text { Inorganic dust } \\
\text { Extractible hydrocarbons }\end{array}$ & $\begin{array}{l}17 \cdot 0 \\
69 \cdot 5 \\
3 \cdot 67 \\
32 \cdot 8 \\
5 \cdot 6\end{array}$ & $\begin{array}{c}25 \cdot 2 \\
58 \cdot 9 \\
3 \cdot 21 \\
27.6 \\
7 \cdot 9\end{array}$ & $\begin{array}{c}6 \cdot 1 \\
56 \cdot 4 \\
3 \cdot 19 \\
22 \cdot 7 \\
3 \cdot 0\end{array}$ & $\begin{array}{c}<0 \cdot 01-150 \cdot 6 \\
2 \cdot 5-293 \cdot 5 \\
0 \cdot 10-17 \cdot 56 \\
2 \cdot 0-155 \cdot 5 \\
0 \cdot 1-50 \cdot 0\end{array}$ \\
\hline
\end{tabular}

*These are in units of concentration times hours per day times years. Sulphur dioxide concentration is in ppm and all others are in $\mathrm{mg} / \mathrm{m}^{3}$. (See text for explanation.)

Table 7 Correlation coefficient matrix for cumulative exposure variables

\begin{tabular}{|c|c|c|c|c|c|}
\hline & $\mathrm{SO}_{2}$ & $\operatorname{Resp}$ & $Q t z$ & Inorg & Hydcarb \\
\hline $\begin{array}{l}\text { Sulphur dioxide } \\
\text { Respirable dust } \\
\text { Quartz dust } \\
\text { Inorganic dust } \\
\text { Extractible hydrocarbons }\end{array}$ & 1.0 & $\begin{array}{l}0.743 \\
1.0\end{array}$ & $\begin{array}{l}0.751 \\
0.904 \\
1.0\end{array}$ & $\begin{array}{l}0.524 \\
0.907 \\
0.762 \\
1.0\end{array}$ & $\begin{array}{l}0.805 \\
0.751 \\
0.715 \\
0.494 \\
1.0\end{array}$ \\
\hline
\end{tabular}


respirable particulate exposure was $56.4 \mathrm{mg} / \mathrm{m}^{3} \times \mathrm{h}$ year, which might represent four hours a day exposure to $0.7 \mathrm{mg} / \mathrm{m}^{3}$ for 20 years, or eight hours a day exposure to $0.47 \mathrm{mg} / \mathrm{m}^{3}$ for 15 years. Table 7 shows the correlation coefficients of the cumulative exposure variables with each other. The inorganic and quartz content dust variables were both highly correlated with the total respirable particulate. Sulphur dioxide exposures showed less correlation with the dust variables. The extractable hydrocarbon content of the dust also behaved somewhat independently of the other air contaminants.

\section{Discussion}

\section{EXPOSURES IN 1980}

The $\mathrm{SiC}$ process and work activities produce several air contaminants: carbon monoxide, sulphur dioxide gases, and respirable particulate containing $\mathrm{SiC}$, crystalline silica ( $\alpha$-quartz and traces of cristobalite), and other inorganic and organic materials. All but carbon monoxide can produce adverse respiratory effects.

The median exposures to sulphur dioxide and respirable particulate were all well below the allowable exposures for Quebec and the United States. Varying amounts of crystalline silica and extractable organic material were found in the particulate. The high temperature of the process, approximately $2100^{\circ} \mathrm{C}$, would be expected to convert a portion of the quartz into trydimite (formed at $870^{\circ} \mathrm{C}$ ) or cristobalite (formed at $1470^{\circ} \mathrm{C}$ ) or both.$^{14}$ Only traces of cristobalite were found; most of the crystalline silica was $\alpha$-quartz. Perhaps the reaction that forms SiC removes the quartz before it can be converted into trydimite or crystobalite. The geometric mean quartz levels were well below the permissible exposures for all jobs except the furnace loaders, whose geometric mean equalled the current limit of 100 $\mu \mathrm{g} / \mathrm{m}^{3}$ for eight hours. The composition of the other inorganic constituents of the particulate was uncertain and needs further study.

Organic compounds were a significant part of the exposures of some of the furnace area jobs: cranemen and carboselectors. Because of the similarity between the $\mathrm{SiC}$ and coke oven processes, similar types of hydrocarbons were probably present in the emissions from both. Because the SiC process uses coke rather than coal, however, the lighter hydrocarbons which were removed during coking will not be present, but the larger fragments produced by pyrolysis of the carbon will be released. Fluorescent spot tests showed the presence of polycyclic aromatic hydrocarbons in the extracts of the furnace area particulate. These compounds may contribute to the risk of lung cancer among the furnace area workers.
Some of the other organic compounds are likely to be irritants, such as aldehydes or organic acids. Further work is needed to identify the nature of these materials.

Although cigarette smoking at work was widespread, only the carboselectors showed evidence of significant nicotine in their respirable dust samples. This was discovered because the carboselectors had substantially more extractable organic material $(20 \%)$ in their samples than the other furnace area jobs which had 1.6 to $9.3 \%$ extractables. Initially it was hypothesised that the additional material came from the collection of cigarette smoke in the lunchroom where the carboselectors wait between work periods. However, the amounts of nicotine did not increase and decrease with the amounts of extractable materials. Thus the carboselectors are apparently exposed to more extractable materials than expected, but the source of this exposure is not clear.

Table 4 shows that the $\mathrm{SO}_{2}$ and dust exposures of the job categories were not closely correlated: cranemen had high $\mathrm{SO}_{2}$ and low dust exposures, whereas carboselectors had low $\mathrm{SO}_{2}$ and high dust exposures. This suggested that it may be possible to distinguish between the effects of $\mathrm{SO}_{2}$ and respirable dust (and the constituents of the dusts) by contrasting the respiratory status of workers in different jobs.

\section{ESTIMATION OF LONG TERM EXPOSURES}

Retrospective estimation of exposures was possible because the facility and operations were very stable over a long period (1962-80), and only one work area and set of four jobs had changed before 1962 . Thus the 1980 survey results were probably representative for 1962-80 and with some modification satisfactory for pre-1962. Therefore, given a worker's job history, his exposure at any point in time could be estimated.

An objective of this study was to develop estimates of the dose of inhaled air contaminants for each subject so that exposures could be related to respiratory effects in the epidemiological study. We selected cumulative exposure (duration times intensity) as our dose index because it is proportional to the total amount of contaminant deposited or absorbed in the subject's lungs. This proportionality has two caveats. Inhalation rates depend on the body size and work efficiency of the worker as well as the ergonomic demands of the job. Even if the average inhalation rates are about the same for all the workers doing a given job, different jobs frequently have different energy demands which will require different breathing rates. Thus even though the cumulative exposure is the same for two jobs, 
the cumulative dose to the lungs may not be. Similar observations may be made about the fraction of dust deposited in the lungs for a given job. If the job changes the particle size distribution may change also, which will alter the fraction of dust deposited in the lungs, and change the proportionality between exposure and dose. Thus the proportionality between exposure and dose in this study was only approximate.

The cumulative exposure index has an important shortcoming in that it is not affected by dose rate, which may be important in the toxicological mechanism of the health effects. Thus it gives equal weight to short term high exposures and to long term low exposures. If the effect is one of slow accumulation of damage and secondary responses, then dose rate may be relatively unimportant. If the effect is caused by the accumulation of acute damage produced by brief peak exposures then cumulative exposures may be a poor index of dose.

The cumulative exposure approach has the advantage of providing a mechanism to analyse complex work histories and multiple agent exposures. For example, a worker's job history can provide the duration of exposure for his exposure to both respirable particulate and sulphur dioxide. As long as the exposures are not highly correlated in every job, the cumulative exposures will be independent and will permit assessment of the independent effects of the exposures.

The cumulative exposures were calculated from the median exposures of workers performing the jobs. Clearly some error is introduced by using the group median instead of the subject's personal exposures. The analysis of variance in table 5 showed that there was less variability in average exposure between workers than there was day to day for individuals doing the same job. Thus this may not be a major source of error in estimating the cumulative exposures. An extensive discussion of the derivation and statistical characteristics of this error are given in another paper ( $\mathrm{T} \mathrm{J}$ Smith, in preparation).

The correlation coefficients between the cumulative exposures of the various air contaminants (table 7) showed that there was insufficient independence between some of them to allow the assessment of their independent effects, even though the individual jobs varied considerably in their exposures for the air contaminants. The independent effects of sulphur dioxide, total respirable particulate, and extractable hydrocarbon content of the particulate could be assessed. The loss of ability to distinguish the exposures to the inorganic constituents was probably the result of their similar concentrations in the furnace area particulate, and the frequent job changes made by nearly all of the workers, which would have the effect of averaging out the differences between the jobs; one worker had changed jobs 45 times during his tenure at the plant. It may have also been caused by the relatively large error and small number of samples collected to measure the exposures. A follow up study is in progress to obtain more extensive exposure data over a two and a half year period, which will improve the quality of the exposure estimates.

This work was supported by a grant from the Départmente de Santé Communautaire, Centre Hospitalier Régional de la Mauricie, Shawinigan, Quebec, Canada, and by the Occupational, Environmental Health Center Grant No ES0000220 from the National Institute for Environmental Health Sciences. We gratefully acknowledge the help of Dr René Tremblay, Jacque Ciccioli, and Claude Bleauin.

\section{References}

' Bruusgaard A. Pneumoconiosis in silicon carbide workers. Proceedings of the Ninth International Congress on Industrial Medicine. London. 1948;13-7.

2 Clark WI. The dust hazard in the abrasive industry: second study. J Ind Hyg 1929;11:92-6.

${ }^{3}$ Clark WI. The dust hazard in the abrasive industry. $J$ Ind Hyg 1925;7:345-51.

${ }^{4}$ Gardner LU. Studies on the relation of mineral dusts to tuberculosis. III. The relatively early lesions in experimental pneumoconiosis produced by carborundum inhalation and their influence on pulmonary tuberculosis. American Review of Tuberculosis and Pulmonary Diseases. 1923;7:344-57.

s Engelbrecht FM, Thiart BF. The effect of small amounts of aluminium, carbon and carborundum on the development of silicosis and asbestosis. $S$ Afr Med J 1972;46:462-4.

- Peters JM, Smith TJ, Bernstein L, Wright WE, Hammond SK. Pulmonary effects of exposures in silicon carbide manufacturing. Br J Ind Med 1984;41:109-115.

7 Taylor DG. NIOSH manual of analytical methods. Vol I. DHEW (NIOSH) publication No 77-157A. Washington DC: US Government Printing Office, 1977;259-1 to 259-7.

${ }^{8}$ Smith TR. Evaluation of sensitized fuorescence for polynuclear aromatic hydrocarbon detection. PB80-108475, National Technical Information Service (NTIS), EPA Report No EPA-600/7-79-207, Aug 1979.

- Grubner O, First MW, Huber GI. Gas chromatographic determination of nicotine in gases and liquids with suppression of adsorption effects. Anal Chem 1980;52:1755-7.

10 Taylor DG. NIOSH manual of analytical methods. Vol I. DHEW (NIOSH) publication No 77-157A. Washington DC: US Government Printing Office, 1977: 146-1 to 146-7.

"Leidel NA, Busch KA, Lynch JR. Occupational exposure sampling strategy manual. DHEW (NIOSH) Publication No 77-173. Washington DC: US Government Printing Office, 1977;1227.

12 Statistical Analysis System (SAS) Institute, Inc. SAS users guide. Raleigh, NC: SAS Institute Inc, 1979.

${ }^{13}$ Colquhoun D. Lectures on biostatistics. An introduction to statistics with applications in biology and medicine. Oxford: Clarendon Press, 1971;78-80.

14 Iler RK. The chemistry of silica. New York: John Wiley and Sons, 1979:15-6. 